Article

\title{
Evaluation of Ecological Criteria of Biofuel Certification in Germany
}

\author{
Kirsten Selbmann ${ }^{1,2, *}$ and Lydia Pforte ${ }^{3}$ \\ 1 Potsdam Institute for Climate Impact Research (PIK), Jägerallee 15, 14469 Potsdam, Germany \\ 2 Environmental Policy Research Centre (FFU), Freie Universität Berlin, Freie Ihnestrasse 22, \\ D-14195 Berlin, Germany \\ 3 Meo Carbon Solutions, Hohenzollernring 72, D-50672 Köln, Germany; lydia_pforte@web.de \\ * Correspondence: selbmann@pik-potsdam.de; Tel.: +49-331-5814610
}

Academic Editor: Michael Wachendorf

Received: 16 June 2016; Accepted: 2 September 2016; Published: 13 September 2016

\begin{abstract}
The share of biofuels has increased significantly over the last decade, which has lead to several negative impacts on the environment. As a solution, several governments worldwide have promoted the use of certification systems, which have been implemented and in some cases have even been established as mandatory regulations. Due to the focus of the public debate, standard-setting has mainly been limited to developing and newly industrializing countries. Hence, the issues of environmental impacts as a consequence of agricultural intensification in Germany has been given little attention, and the question whether existing biofuel certification systems sufficiently cover ecological issues remains. In order to answer this question, this study performs a benchmarking analysis of selected certification systems, whereby their ability to ensure ecological sustainability is evaluated and compared. The assessment reveals that the currently existing national ordinances, like Cross Compliance, are in many aspects insufficient to ensure sustainability. Contrarily, they often deter necessary discussions to tackle these issues.
\end{abstract}

Keywords: biofuel certification; biofuel policy; EU RED; Cross Compliance; Germany

\section{Introduction}

In the light of global climate change and rising oil prices, biofuels were considered a promising solution for sustainable development. Especially in the area of mobility, which holds enormous potential in terms of reducing greenhouse gas emissions, alternatives to motorized transport on the basis of fossil fuels were sought. Biofuels were presented as a sustainable approach to solving problems of climate, energy and agriculture. As an effect, biofuel production increased worldwide; the production of bio-ethanol for instance tripled between 2000 and 2007 with the USA being the largest and Brazil the second largest producer worldwide [1]. The production of bio-ethanol is mainly based on corn (USA), sugarcane (Brazil) or sugar beet and wheat (Europe). The European Union (EU) is another important player, especially concerning the production of biodiesel, with a global market share of 60 percent in 2007 [1]. Biodiesel is produced by refinement of vegetable oils, mainly from rapeseed, soybean and palm oil.

The article focuses on the production of 1st generation biofuels (1st generation biofuels typically refer to vegetable oils, biodiesel and bioethanol, produced by established physical-chemical (pressing, extraction, and esterification) or biochemical (alcohol fermentation) processes; 2nd generation biofuels, in contrast, subsume predominantly synthetic biofuels such as BtL (biomass-to-liquid, and Fischer-Tropsch-diesel), biomethane, or bio-SNG (synthetic natural gas), as well as bio-hydrogen, produced by thermo-chemical processes (gasification, pyrolysis) [1]) in the European Union. Since the early 1990s, political discussion at EU-level has highlighted various positive properties of biofuels [2], 
e.g., the need for only marginal technical adjustments in the automotive industry, lower GHG emissions than fossil fuels, the creation of jobs and a decrease in the dependency on oil imports. These and other advantages provided the impetus for political action within the European Union [1,3], which also led to aincreased biofuel production (see Figure 1).

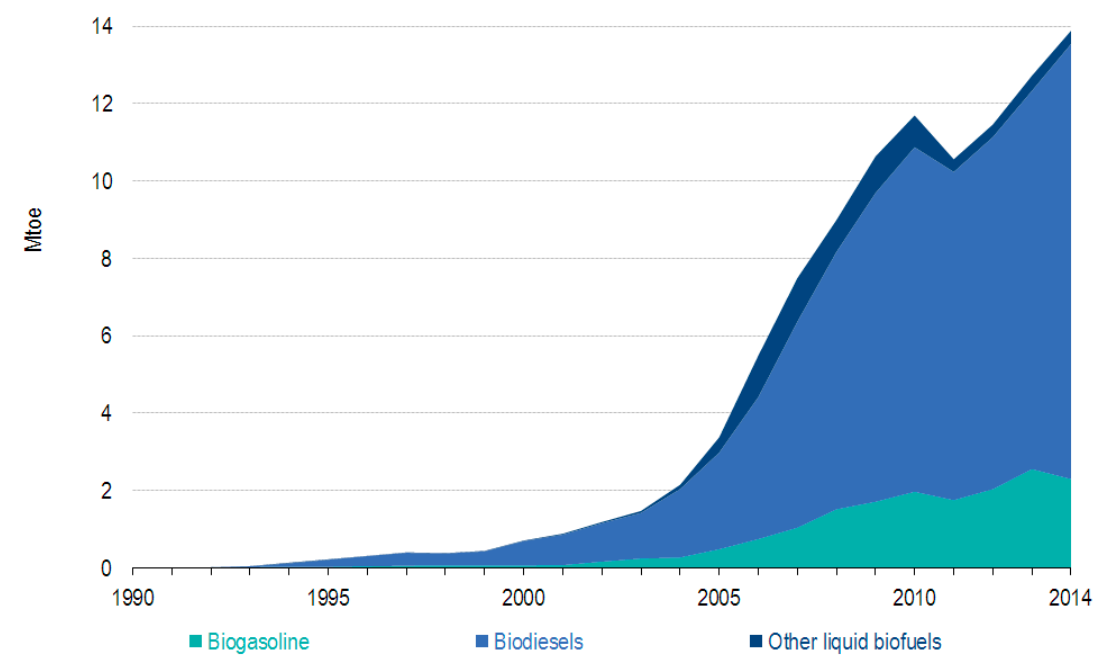

Figure 1. EU28 Liquid Biofuels Production 2014. Source: Eurostat.

The high biofuel demand in the EU, has incentivized a stronger production outside the EU, e.g., in Indonesia or Brazil. In the last few years, the media and environmental organizations have revealed severe negative effects of increased biofuel production in third world countries leading to public controversy [4]. This critique peaked in 2007, when several studies including one published by the Organisation for Economic Co-operation and Development (OECD) linked biofuel production to food shortages, biodiversity loss and both direct and indirect land-use change. Further negative (in)direct results of an increased biofuel production, especially in developing and emerging countries, are: the expulsion of smallholders and indigenous people from their land, deforestation, local food insecurity if food cultivation is abandoned in favor of soy, oil palm, or sugarcane plantation for biofuel production or health hazards due to the use of agrochemicals [5-10]. As a result, governments felt the need to intervene and started to reduce obligatory biofuel quotas. Additionally, the EU and some of its member states began to focus on a program of certification to ensure the sustainable production of biofuels [11].

This study will assess to what extent environmental considerations are addressed by the obligations of two EU member states (Great Britain and Germany), being the Renewable Transport Fuel Obligation (RTFO, building on the RTFO framework as it exists prior to 2011) and the Biofuel Sustainability Ordinance (BSO), and the three voluntary certification systems that existed in 2010 for biofuel certification. The three voluntary schemes are REDcert, the International Sustainability and Carbon Certification (ISCC) and the Roundtable on Sustainable Biofuels (RSB) and were implemented in Germany and Great Britain. Furthermore, as a requirement of the certification schemes we will assess Cross Compliance which is an obligatory tool set by the European Commission (EC). It poses 19 requirements on agricultural cultivation, which have to be fulfilled by European farmers in order to receive direct payments [12]. Thereby, it shall warrant sustainability in agriculture. This tool plays an important role in the implementation of certification systems in Germany, because almost all analyzed approaches assume that sustainable agricultural production in Europe is guaranteed by fulfilling the requirements of Cross Compliance. Thus, it is integrated in the analysis.

As the certification systems should be able to cover regional issues, the study will apply an explorative regional approach to evaluate the performance of the certification systems within the state of Brandenburg. Brandenburg was chosen as case study because the production capacity of 
biodiesel accounted for 19.7 percent of total capacity in Germany already in 2006 [13]. Through this spatial concentration of feedstock cultivation area, Brandenburg was evaluated to show ecological impacts of biofuel production and associated competition for utilization in plant production and nature protection purposes.

The objective of this work is to analyze and evaluate the ecological performance of existing certification systems. Guided by the objective of understanding the impacts of the available approaches on the environment, we will determine whether the systems include appropriate criteria to minimize potential negative ecological impacts. The focus is on ecological impacts within Germany, as the issues of intensification and pressure on agricultural land have received insufficient attention in the debate surrounding sustainable biofuels [14-17].

Existing studies on risk related to biofuel production within developing countries have produced recommendations regarding important criteria for certification schemes or the certification of biomass $[18,19]$. However, little research has addressed the impacts of certification in Germany. In this respect, it is necessary to assess the legal framework of the Cross Compliance mechanism of the Common Agricultural Policy (CAP) of the European Union (EU), as it is a precondition for the analyzed certification schemes. Benchmarks have been provided by authorities within the accreditation process for certification systems, although this has been mainly for existing agricultural or forestry standards [20,21]. Henneberg et al. [22] concluded that a benchmark of different certification approaches was appropriate to adress biodiversity issues. This study produces an analytical benchmark consisting of different environmental factors that were considered central to biofuel production by scientific and political debates. The benchmark will be used to analyze and compare the environmental standards of the analyzed regulatory frameworks and certification schemes. As an additional result of this analysis, we will identify and discuss potentials and shortcomings and extract factors that are considered central for a policy mechanism to effectively ensure sustainable biofuel production.

In the past, sustainability standards have primarily been used voluntarily in the agricultural and forestry sector. They have been developed in a multi-stakeholder-consensus grounded in a risk-based approach [23]. In this way, a wide range of stakeholders have been included in the standard setting process along with experts [24]. All stakeholders need to agree on the standards to be applied $[18,25]$ and so voluntary sustainability certification can be classified as a bottom-up-approach. A successful example in terms of participation and scope is the Forest Stewardship Council (FSC). Starting in 1993, today there are over 800 members (e.g., companies, environmental and indigenous peoples' organizations) certifying forests in 81 countries. In 2013, there were 180 million hectares FSC certified [26].

Voluntary certification systems are, however, extremely fragile and depend on the acceptance of all stakeholders. Acceptance depends on the independence of all parties involved in the process, avoidance of conflicts of interests, and a transparent and traceable supply chain. Independence is provided by the structure of the certification system, which is both a standard-setting certification system and a standard-controlling certification body. Transparency and traceability of the certification system are guaranteed, inter alia, by a chain of custody, which is installed to monitor the attributes of a sustainable good along the whole supply chain to the consumer [27]. Therefore, different critical interfaces, e.g., cultivation, processing, conversion, manufacturing and allocation, must be identified in order to monitor the performance of the systems [19].

Until now, in forestry and agricultural certification, the highest risks have been identified in cultivation. Hence, the chain of custody only had to ensure that there was no mixing of sustainable and unsustainable products and no decoupling of the certificate from the physical product occurred in the following stages. However, with the emergence of biofuel certification, a new greenhouse gas emission (GHG) criterion was introduced. The certification of GHG balances requires a suitable measurement method, which needs to be implemented throughout the whole supply chain [28]. As this requires data to be gathered for each interface, the scope of the certification is extended from the cultivation to the whole product chain [28]. Hence interfaces, which until now have simply represented the transfer 
of the physical product together with the attached documentation to the next interface, now also need to determine and forward GHG emission credits in the supply chain to the end user. The end-user is, in turn, obliged to report the reduction in GHG emissions, compared to conventional fuels in order to receive tax incentives or to be accepted in the quota system.

With an increasing awareness of issues associated with biofuel production, different national strategies have been developed to fight these undesirable issues within a short time frame. Thereby, the approach of a meta-standard was chosen, which accredits existing standards against their own present regulations regarding minimum requirements of certification processes, the chain of custody and sustainability principles $[1,28,29]$. The task of certification is executed by the approved certification systems and bodies [30].

\section{Methods}

This study analyzes environmental standards incorporated in the legal frameworks of selected biofuel policies according to a list of benchmark criteria. Based on existing literature a list of benchmark criteria was developed. In order to produce an insightful perspective on regulatory mechanisms and their potentials and shortcomings of their legal design and implementation, expert interviews were conducted. The interviews were also used to ensure that the analytical framework was comprehensive and covers all relevant aspects of the environmental risks of biofuel production in Germany. Several benchmark criteria reflect the negative aspects of increased feedstock cultivation of first-generation biofuels in Germany. These mainly include rapeseed for biodiesel as well as maize, winter wheat and winter rye for bio-ethanol.

We used "guided expert interviews" as an explorative tool. As an interview sampling strategy we identified experts according to their "specialist knowledge" and made sure to represent a variety of actor groups [31]. In order to produce a general evaluation, we selected experts that represent all different stakeholder groups involved in the design and implementation of the selected biofuel policies. The qualitative, semi-structured interviews serve as an explorative, highly detailed methodology to identify strengths and weaknesses of the policies on a meta-level. Building on the results of this study, it will be interesting to conduct a survey among farmers and stakeholders along the value chains to produce quantitative evidence on the performance of the different regulatory frameworks.

The guided interviews conducted for this study are not standardized and thus cannot be quantitatively evaluated [32]. Expert interviews cannot provide completely objective information as they are always subject to bias [33]. Therefore, the interviewer needs to be aware of certain positions on a subject [32]. Another characteristic of the guided interview is the so-called "audience effect" whereby the interviewee expects an audience reaction. According to Bogner and Menz [32], this effect can result in qualitative inaccuracy and limited reliability. Being aware of these problems, the expert interviews in this paper function as a tool to gain insider knowledge and to get ideas about problems and shortcomings of certification systems. Thus, they function only as a supportive source of information, while the results predominantly are based on the benchmarking.

In this study, experts with knowledge of the ecological impacts of biofuel cultivation are chosen. Several representatives of NGOs as well as political institutions, associations and consultancies are: Ulrike Kallee from Greenpeace, László Maráz from the Forum Environment and Development (FUE), Franziska Mey from the World Wide Fund (WWF) reflect the opinions of the NGOs. The reason why three different organizations have been interviewed is the different opinion of the NGOs concerning biofuel certification as a tool to guarantee sustainability. While Greenpeace is against biofuel certification at all and favors the tool of regionalization to ensure sustainability, the WWF supports certification systems, even as an active stakeholder. Thus, the target of the interviews was to include contrasting opinions and experiences. The expert of the FUE manages the "platform sustainable biomass". He has been identified to contribute clustered knowledge of different German nature protection associations, which are all members of this platform. 
Christoph Molkenbur from the Ministry of Environment, Health and Consumer Protection (MUGV), Irene Kirchner from the Ministry for Infrastructure and Agriculture (MIL), and J. Zimmer from the LELF (a regional authority for rural development, agriculture and land consolidation) were chosen to include the regional ecological and agricultural issues. The German Farmers' Association (DBV) and an expert of REDcert have been interviewed to contribute substantial knowledge about the economic practicability of the certification systems. The expert of the DBV mainly represents the interests of farmers. In order to include insider knowledge on economic practices throughout the remaining value chain interfaces (oil mills, biofuel supplier, etc.), the REDcert certification system has been included (by the end of the interview period in October 2010, 107 companies working along the value chain had been certified). Furthermore, two experts from the Ecologic Institute, Jessica Loehndorf and Timo Kaphengst, were interviewed. They represent the link between the sustainable design of biomass certification approaches and practicability. One of the experts even participated in the process of drafting the BSO.

To guarantee sustainability, the setting of standards should be grounded in a risk-based approach. As German agriculture becomes more intensive, the greatest risks of biofuel production occur on and around the cultivation sites. They include risks to (agro-)biodiversity and negative impacts on soil, water, plants and air. Literature analysis and the expert interviews identify the following risks, which affect the ecological benchmark criteria:

- Intensification of areas with high conservation value [34];

- Intensification/plowing of grassland [35,36];

- Loss of areas with high carbon stock $[17,34]$;

- Deterioration of water quantity [37,38];

- Loss of agrobiodiversity (structural diversity and crop varieties $[22,35,39,40]$, (included after the expert interview with J. Zimmer);

- Increased soil erosion [22,41];

- Decreasing soil fertility and loss of soil structure ([35,42-45], (included after the expert interview with J. Zimmer);

- Disturbed fertilizer application and pest management [46];

- Increasing use of genetically modified organisms (GMOs) ([47], (Expert interview with L.P.)); and

- Increasing greenhouse gas emissions.

The standard on GHG emission balance, which is an important part of the certification of biofuels and needs to be generated in order to verify the emission reduction, only briefly features within the two national strategies. This is because there is currently no actual data available for the GHG emission balance; default values are used. The above criteria were discussed with interviewees to assure they cover all relevant risks related to biofuel production.

\section{Results and Discussion}

In this section, the three voluntary schemes RSB, REDcert and ISCC, as well as the legal regulations RTFO and BSO will be assessed against the defined sustainability benchmark criteria (see Table 1 for an overview). Due to the linkage with Cross Compliance, BSO, REDcert and ISCC require an elaborated set of abiotic criteria, such as soil erosion and fertility, water quantity or agrochemicals. These legal obligations do however not require farmers to produce monitoring data to verify compliance, and violations of Cross Compliance do not automatically involve sanctions (according to §51 of the BSO framework [48]). It therefore becomes apparent that BSO, REDcert and to a lesser extent ISCC do not assure compliance with abiotic criteria. ISCC is a special case, as it integrates some additional criteria into its standard, which are not covered by Cross Compliance. Even though ISCC does not require European farmers to comply with these criteria [49], it is included in the benchmark assessment in order to evaluate whether their implementation could positively influence the ecological situation in Europe. 
Table 1. Benchmark of the different certification systems in terms of ability to approve sustainability $[12,20,49-52]$.

\begin{tabular}{|c|c|c|c|c|}
\hline & $\begin{array}{l}\text { Cross Compliance as Implemented in } \\
\text { the State of Brandenburg }\end{array}$ & BSO REDcert * & RTFO ** & RSB \\
\hline $\begin{array}{l}\text { Areas with high biodiversity, } \\
\text { high conservation value }\end{array}$ & $\begin{array}{l}\text { Council Directive } 79 / 409 / \mathrm{EEC} \\
\text { 92/43/EEC (no significance for biofuel) }\end{array}$ & $\S 1$ criterion 1.1 (ISCC) & criteria $1.1,2.2$ & criteria $1 \mathrm{a}, 7 \mathrm{a}, 7 \mathrm{~b}$ \\
\hline Grassland & & $\S 1.3$, criterion $1.2($ ISCC) & $\underset{\text { criterion } 1.1}{1}$ & criteria 2a, 7a \\
\hline $\begin{array}{l}\text { Areas with high carbon stocks } \\
\text { (without grassland) }\end{array}$ & $\begin{array}{l}\S 30 \text { BNatSchG, guideline on conservation } \\
\text { of wild birds (no significance for biofuel) }\end{array}$ & $\underset{\S \S 2.1-2.2,3.1, \text { criteria } 1.3,1.4 \text { (ISCC) }}{\text { D }}$ & $\bigodot_{\text {criterion } 1.1}$ & $\underset{\text { criterion } 2 \mathrm{a}}{\mathrm{O}}$ \\
\hline Water quantity & Council Directive 86/278/EEC & $\bigcirc \quad \underset{\text { Criterion } 2.9}{\mathbf{D}}$ & $\begin{array}{c}\text { D } \\
\text { criteria } 4.1,4.2\end{array}$ & criteria $7 \mathrm{~b}, 9 \mathrm{~b}-\mathrm{d}, 11 \mathrm{a}$ \\
\hline Crop rotation & \$3, appendix III, 86/278/EEC & & & $\curvearrowright$ \\
\hline Structural diversity & $\underset{\S 5}{\S}$ & & $\overbrace{\text { criterion } 2}$ & $\underbrace{}_{\text {criteria } 7 \mathrm{~b}, \mathrm{~d}}$ \\
\hline Buffer zones & $\begin{array}{c} \\
\begin{array}{c}\text { Council Directive 91/676/EEC, } \\
\text { appendix III }\end{array}\end{array}$ & $\begin{array}{c}\text { D } \\
\text { criterion } 2.2\end{array}$ & & $\begin{array}{c}\text { criteria } 7 \mathrm{a}, \mathrm{c}, 9 \mathrm{~d} 1 \\
\text { che }\end{array}$ \\
\hline Soil erosion & $\underset{(\S \S 2,5)}{1}$ & & criterion 3.2 & principle 8 \\
\hline Soil fertility and structure & §3, appendix III, 86/278/EEC & & criteria $3.1,3.2$ & criterion 8a1,10b1 \\
\hline $\begin{array}{l}\text { Fertiliser application, pest } \\
\text { management }\end{array}$ & $\begin{array}{c}\text { D } \\
\text { Council Directives 91/676/EEC, } \\
\text { 80/68/EEC, 91/414/EEC }\end{array}$ & $\begin{array}{c}\text { ( } \\
\text { criteria } 2.7,2.10 .5,2.10 .6\end{array}$ & $\begin{array}{c}\text { D } \\
\text { criteria } 4.1,4.2\end{array}$ & $\begin{array}{c}\text { D } \\
\text { criteria } 8 \mathrm{a}, 11\end{array}$ \\
\hline GMO & O & ) & D & $\underset{\text { criterion 11a }}{\mathbf{D}}$ \\
\hline
\end{tabular}




\subsection{Areas with High Conservation Value}

The recognition of international, regional and local protected areas is a condition to all analyzed certification systems. BSO, REDcert and ISCC exclude two designated areas from any type of usage: primary forests and natural grassland with high biodiversity [53]. Aside from the areas defined by the habitats and bird directive that are linked to the Cross Compliance mechanism (e.g., Natura 2000 sites) [12], the analyzed certification schemes cover all designated reserves in Germany, including nature reserves, protected landscape areas, national parks and designated zones in biosphere reserves [48].

All types of protected areas allow agricultural cultivation outside the core zone (zone I, see e.g., [54]). At the same time, certain restrictions determined by the reserve regulations must be considered, such as bans on the use of pesticides, grassland plowing or specific requirements on the time of mowing [12]. Additionally, the farmer can participate in voluntary programs such as contractual nature conservation or cultural landscape protection programs (KULAP). These include measures such as extensive grassland usage, maintenance of dry grassland or, until 2007, the permanent set-aside of ecologically sensitive areas $[55,56]$. The requirements of landscape protection areas often seem vague and include fewer restrictions than nature reserves [57]. According to C. Molkenbur (MUGV), the objective of landscape protection areas is to preserve and promote the landscape, and thereby providing ecosystem services, such as recreation areas and scenic beauty. Management plans must be generated for the Natura 2000 areas, which define precise measures to promote the servicing and development of the conservation values. C. Molkenbur (MUGV) notes that their legal framework provides a more specific guidance for implementation than other protected areas (in German: Naturschutzgebiete) and have higher regional relevance. However, because they are optional and voluntary, there is no legal basis for these higher requirements. RSB is implemented in a more elaborated process, requiring a regionally specified land-use impact assessment for every planned site [52]. Possible risks of feedstock production on the conservation values are evaluated not only by including maps or databases, but also by consulting relevant national or regional experts and including local stakeholders. There is no statement of how endangered ecosystems should be treated. However, because areas with conservation areas valued by the local, regional or global level need to be maintained or even enhanced, the limitations for biofuel production increase with rising environmental impact on a site [52]. This approach is desirable, especially in countries where areas of high conservation value are not yet defined. In Germany with its well-developed structures and conservation areas, this approach may be too complex and long-winded and may therefore deter the implementation by farmers.

\subsection{Grassland}

Cultivation of natural grassland with high biodiversity is completely prohibited; the cultivation of artificial grassland with high biodiversity, as well as wet meadows, is allowed as long as it does not lead to a degradation of the existing state. However, when considering artificial grassland, the status does not take into account biodiversity [58]. Several experts criticize the specification of grassland within the BSO. As one of them, T. Kaphengst (Ecologic Institute) claims that the BSO definition of grassland is too vague for practical implementation. Extensively cultivated grasslands can be converted to intensive use by mowing to a maximum of 5-6 times per year and a fertilizer application of up to $170 \mathrm{~kg}$ / (ha.year) [12]. The conversion or intensification of the use of wet meadows is more difficult, as the status refers to specific measures for water coverage and penetration. RSB allows the usage of all kinds of grasslands as long as the status is maintained [52]. However, in contrast to the $\mathrm{BSO}$, the status of RSB is dependent on the status of the conservation value, which is identified through the previously mentioned land-use impact assessment (criterion 7a of [52]). In this way the risk of intensification of ecological sensible grasslands and wet meadows can be minimized. The British RTFO effectively solves the problem of grassland handling by excluding all areas where carbon payback time would exceed 10 years. In Germany, this would imply a prohibition of any land-use change of 
grassland to an agricultural cultivation comprising wheat for bio-ethanol or rapeseed for biodiesel (methyl ester, ME) [20]. However, no particular recommendation is given by the RTFO for the type of cultivation of grasslands with high biodiversity. Hence, in the case of crops with higher GHG emission reduction potential in comparison to the first-generation biofuels, a plowing of grassland with high biodiversity cannot be prevented.

\subsection{Areas with High Carbon Stock}

Areas with high carbon stock, such as forests, peat lands or wetlands which are swamps or marshes, are protected by all the certification schemes. BSO, REDcert and ISCC protect forests with an area of more than one hectare and a tree height of at least $5 \mathrm{~m}$, by arranging them into different protectable categories depending on their canopy cover (criterion 5.2 of [48]). The definition of "canopy cover" is controversial, especially in terms of identification and specification scope. The preservation status of forests with a canopy cover of less than $10 \%$ is critical, as these are not preserved at all. Forests with a canopy cover of $10 \%-30 \%$ can be used as long as the status of forest is maintained. However, this refers to the status of a forest, not the status of conservation value.

The agricultural use of internationally accepted wetlands, like those designated under the RAMSAR-Guidelines [59], or wetlands which are completely waterlogged, is prohibited. All other wetlands or peat lands can be used, as long as the status is maintained. In this instance the status of peat land refers to the organic matter of the soils, and the status of wetland to the water coverage or water saturation. A typical soil of a peat land should show an organic matter mass portion of at least $20 \%$ of the fine soil up to a depth of $60 \mathrm{~cm}$ of the diagnostic horizon [58]. However, it is not specified how this is determined. Therefore, it is assumed that in Germany only wetlands or peat lands, which are already recognized under internationally accepted guidelines, are addressed, while all other areas are assumed to be in conditions not worth protecting.

The RTFO uses the same approach for soils with high carbon stock as that for grassland. It includes a time limit for the carbon amortization [20], requiring stakeholders to calculate the payback time of a land-use change. If the carbon payback time exceeds 10 years, a land-use change is prohibited. After 2015, when current volume-based quotas will be changed to GHG-based quotas [60], the BSO will also include the measurement of GHG emissions when considering land-use change although there is no limit on amortization time. Currently the effectiveness of the GHG calculation method cannot be evaluated. L. Maráz (FUE) predicts that through the obligation to fulfill the GHG savings, negative land-use change, like the plowing of grassland, will no longer be lucrative. Within the ESIA of the RSB a reference is made to the soil carbon, allowing the usage of peat lands, wetlands or forests if the identified risk in terms of carbon stock and biodiversity is small [23]. The land-use change of less risky areas is allowed as long as GHG emissions are included in the GHG balance.

None of the certification systems include the improvement of the condition of degraded carbon stocks, which is common within Germany. By demanding buffer zones along water courses or springs, RSB [23] as well as ISCC [49] include one of the proposals and place more importance on these criteria than the other certification systems.

\subsection{Water Quantity}

The water quantity criterion is best covered by the RSB. It requires a water management plan as well as measures to reduce water consumption and contamination. It also specifies that irrigation intensive crops should be excluded from long-term stressed water regions. Furthermore, there are progress criteria on the treatment and recycling of waste waters and run-off waters, which are important for the sustainable handling of water sources [23]. However, it is not clear how these criteria should be implemented or verified.

In contrast, Cross Compliance only requires compliance with official procedures, which, as learned from the implementation in Brandenburg, means that an extraction of ground and surface water is only allowed with an approval of the responsible authority, i.e., the lower water authority [12]. However, 
solely limiting water usage can deter acceptance by farmers and other stakeholders. Instead, a more detailed capacity building process shedding light on water impacts of production could potentially initiate a change in attitudes and incentivize ownership for sustainable water management.

The ISCC scheme sets further requirements, demanding efficient irrigation techniques for every plant and recommending water abstraction from sustainable sources [49]. Despite not giving a specified description of required irrigation techniques or water management practices, these requirements can be met by applying good technical practices, as already established in Germany.

The RTFO recommends maintaining records on the water sources as well as the biological oxygen demand and water levels near the sites of biomass production (criterion 4.2 of [61]). These records of the biological oxygen demand are a tool that enables farmers to monitor and sustainably manage their water resources and fertilizer treatment. However, RTFO only gives recommendations and does not condition its certificate on these practices.

\subsection{Agrobiodiversity}

In order to ensure a diversity of crops in agricultural landscapes, Cross Compliance includes the recommendation of crop rotation. If a region integrates this requirement, a farmer has to cultivate at least three cultures, whereby every culture has to cover at least $15 \%$ of the arable land [12]. In other words this means that one crop can account for up to $70 \%$ of the agricultural area without violating Cross Compliance. Thus, Cross Compliance does not stop a further narrowing of crop rotation to improve agrobiodiversity and soil fertility or decrease pest infestation. No standard on crop rotation is set by the RTFO, while for the RSB crop rotation is merely a progress requirement [52]. Thus, the tendency of a diminishing variety of crops cannot be prevented by these certification schemes.

Although, it has been shown before that structural landscape elements play an important role for biodiversity in Germany, none of the German certification systems include any criteria on this issue. Since the abolition of the obligatory $10 \%$ fraction of set-aside land in 2008 [59], only one mandatory tool (the prohibition of the removal of landscape elements) exists to ensure a certain degree of structural diversity in the state of Brandenburg. Hence, it can be concluded that (within the period of conducting this study) no specific policy instrument exists to either protect important landscape features or to connect high conservation value areas.

In contrast to the German Meta-Standard, the RTFO recommends a share of $10 \%$ set-aside of the total agricultural area, and to preserve and even install additional buffer strips or pasture areas as structures for surrounding landscapes [61]. However, as it is merely a recommendation, there is no legal basis for its implementation. Furthermore, because the scheme does not link this measure to specific obligations on diversified agrobiodiversity, the set-aside of land will most likely not have any effect on it. The aspect is best targeted by RSB as it includes a progress requirement to create and rebuild ecological corridors which were destroyed between 1 January 2004 and 31 December 2008 [23]. Additionally, RSB contains a criterion on ecological buffer zones, which are meant to be installed alongside water and conservation areas as well as between the biofuel facility and its surrounding area. ISSC requires the preservation or restoration of buffer strips along natural springs and natural water courses [49], but does not refer to measures buffering conservation areas. Cross Compliance includes a criterion of a 1-3 m buffer strip for fertilization along water courses [12], although it provides no details on the aspired ecological composition of the buffer strips.

\subsection{Soil Erosion}

From 2010 onwards the Cross Compliance requirements cover soil erosion by identifying three erosion risk classes: high risk to water erosion, moderate risk to water erosion and high risk to wind erosion. Depending on the risk classification, plowing is only allowed in certain periods [12]. This approach has been assessed as highly complex, and J. Zimmer (LELF) identifies differences in the level of detail of maps indicating the areas of erosion risks under Cross Compliance, the Federal Soil 
Protection Act and the Water Framework Directive. It has to be emphasized that soil erosion is the only aspect under Cross Compliance that incorporates regional variance.

RTFO and RSB pose similar requirements on defining soil erosion risks. Both expect farmers to implement a soil management plan [62]. RSB defines management strategies by performing an ESIA impact assessment, which takes a highly regionalized approach. Minimum requirements are direct planting and maintaining vegetative ground cover as well as tree hedges [52]. In contrast to the specific requirements in Cross Compliance, RSB does not specify actions to be included into the soil management plan. The RTFO does not even specify the basis of the soil management, therefore lacking regionalism and the inability to verify the documentation of measures. Hence, the most specific requirements in this benchmark criterion are defined by Cross Compliance.

\subsection{Soil Fertility and Compaction}

Except for the criterion on burning stubble fields, all soil fertility criteria covered by the Cross Compliance mechanisms are optional within EU countries [12]. Accordingly, little attention is given to issues of soil fertility.

The Cross Compliance criterion on crop rotation is not considered sufficiently to improve soil fertility. J. Zimmer (LELF) claims that this results from the rotation requirement of cultivating three different crops, instead of crop species. For example the crop rotation of silage maize and "the root crops" potatoes and sugar beets is permitted, even though they all have a heavily humus depleting effect on soils. For this reason, the crop rotation approach is not considered sufficient to combat the issue of decreasing soil fertility.

As an alternative to crop rotation, farmers can provide an annual balance of the organic soil matter content or a soil analysis conducted with a six year sampling frequency. The organic matter of the soil sample should not fall below $1 \%$ for soils with up to $13 \%$ clay content and $1.5 \%$ for soils with more than $13 \%$ clay content [63]. Most of the experts criticize this way of dealing with soil fertility as being too unspecific, especially in terms of soils with very low clay contents as found within the state of Brandenburg (J. Zimmer (LELF)).

In addition to a soil management plan documenting the annual organic soil matter content and measures to preserve and improve it, RTFO requires users to document soil nutrients, $\mathrm{pH}$ and soil salt, whereas residual products should not be used at the expense of long-term soil stability and organic matter content [62]. Requirements on the $\mathrm{pH}$ correspond to the claim of J. Zimmer (LELF) and could be advantageous for the sandy soils within Germany. However, all of the suggested requirements are again only recommendations.

Under the RSB framework, organic soil matter needs to be sampled. Additionally, the RSB requires farmers to report, when the content decreases by applying alternative cultivation practices [23]. In line with the RTFO, the usage of residual products should not result in the expense of long-term soil stability or the alternation of the organic matter content. RSB does not require $\mathrm{pH}$ analyses or soil nutrient balances.

In summary, Cross Compliance, the RSB or the RTFO do not include stringent requirements on soil fertility, crop rotation and soil compaction. Cross Compliance suggests optional requirements concerning appropriate machinery utilization, which, however, has not been adopted in Brandenburg [12].

\subsection{Fertiliser Application and Pest Management}

RSB, RTFO and Cross Compliance incorporate rules for fertilizer application and pest management; ISCC sets some additional criteria on pest management.

In Cross Compliance, fertilizer and pesticide management is regulated through the Nitrates Directive (91/676/EEC), the Ground Water Protection Directive (80/68/EEC) and the Plant Protection Directive (91/414/EEC). Additionally, these directives provide the legal framework for RTFO and $\mathrm{RSB}$, as the two approaches require compliance with national laws. EC 91/676/EEC is the legal basis 
for the German regulation on fertilizers and EC 80/68/EEC the legal basis for the German Water Resources Act (WHG). These regulations specify the storage, handling and disposal of mineral oil products and certain plant protection products [12]. The Nitrates Directive covers the assessment of the total nitrogen content for all organic fertilizers, including livestock manure. Thereby, the content of applied nitrogen in the organic-mineral fertilizers should not exceed the fertilizer required by the crop that follows. Furthermore, the application of fertilizers is only permitted, if the soil is perceptive, i.e., it is not frozen, inundated or waterlogged. Not more than $80 \mathrm{~kg}$ total-N or $40 \mathrm{~kg}$ NH4-N should be used per hectare and application [12]. For the annual average application of livestock manure on arable and grassland the limit is $170 \mathrm{~kg}$ of nitrogen per hectare [12].

All three approaches require a documentation of either records on fertilizer input (Cross Compliance, RTFO), or a soil management plan (RSB).

Despite Cross Compliance requirements, U. Kallee (Greenpeace) and F. Mey (WWF) observe a strong use of fertilizer, particularly in the cultivation of rapeseed and maize. By contrast, J. Zimmer (LELF) points out that intensified fertilizer application is limited by the local cost-benefit calculations. Fertilizer and pesticide application depends strongly on the expected selling price and the costs of supply. He expects higher fertilizer loads only to be applied in cases of crop shortfall after droughts. As the world market price of mineral fertilizers increases, J. Zimmer notes that the application of mineral fertilizers has declined for years. As a remaining issue, limited output quantity is solely controlled for livestock manure. Typical fertilizers of biogas or biofuel plants, such as fermentation residuals, are not considered [64]. Hence, a growth of nitrate input could be detected on sites near biogas or biofuel facilities without being managed by Cross Compliance.

Pest management is still an issue in agricultural cultivation. None of the certification systems require the abandonment of pesticides or even a limit to its use, as desired by experts [46]. Limits are set for the use of fertilizers and nutrient balances, and soil management plans are installed, but the handling of pesticides is simply ensured through "good professional practice". Restrictions are only set by product types. RSB, for instance prohibits the usage of chemicals listed by the World Health Organization (WHO), in Annex III of the Rotterdam Convention, and as persistent organic pollutants (POPs) in the Stockholm Convention. I. Kirchner (MIL) states that during the Cross Compliance surveillance within Brandenburg that are meant to verify compliance with the Groundwater Directive, the storage of pesticides is controlled and pesticide application is documented. However, it remains questionable whether the negative developments of intensified pest management, arising from the increase in growing of pesticide intensive maize and rapeseed, can be prevented. The performance of RTFO is considered even worse; it merely provides recommendations for keeping annual records of agrochemical inputs [62] that do not define base lines or measures for the sustainable use of pesticides.

Although the ISCC refers to Cross Compliance for regulating fertilizer and pesticide application, it also adds some criteria on integrated plant protection deriving from the Directive on Sustainable Usage of Pesticides (2009/128/EC). Options of the integrated pest management include activities in the categories "prevention", "observation and monitoring" and "intervention" [49]. These additional criteria are small enhancements compared to those previously mentioned, because they simply foster an attitude change and an improved handling of pesticides.

\subsection{Genetically Modified Organisms}

The RSB is the only certification system with a criterion on genetically modified organisms (GMOs). However, it only requires a certified producer to inform certification processes on potentially hazardous technologies which include GMOs [23]. No further restrictions concerning GMOs are defined or monitored by the analyzed mechanisms. Implementing a more ambitious standard would require to carefully consult with stakeholders on practicability and costs in order not to lower the acceptance of a certification system substantially. 


\subsection{Limitations of Methodological Approach and Outlook}

Throughout the analyses it becomes apparent that most of the assessed approaches lack sufficient coverage of issues linked to agricultural cultivation in Germany. Most of the experts interviewed note that during the phase of standard-setting of EU RED and BSO, the conditions and interests of developing and newly industrialized countries were particularly considered. This is to a great extent due to the negative developments linked to biofuel feedstock cultivation in these countries, such as the deforestation of savannahs and primary forests or the debates about "fuel tank or dinner plate". This is one of the reasons why concerns regarding the risks of feedstock cultivation in Europe are not properly considered.

Based on these results, further research is required of all certification systems being finally in operation and an impact on agriculture and environment should be made visible through field surveys or other quantitative assessments. This research will be important in order to adjust criteria of certification approaches and review the experts' statements in their accuracy. Especially when GHG-emission reductions will be implemented, impacts of required changes in cultivation should be object of further research.

\section{Conclusions and Policy Implications}

The detailed analyses of the sustainability benchmark criteria point to significant shortcomings in the ability of revised certification schemes and regulatory frameworks to assure sustainable biofuel production. Especially the criteria on agrobiodiversity and soil fertility are not considered adequately to stop intensification of agricultural land-use and biodiversity loss in Germany. In terms of ecological impacts of agriculture, it is questionable whether the benefits of such low requirements outweigh their costs. The RTFO provides additional recommendations to improve sustainability, like $\mathrm{pH}$-measurements or water management. Unfortunately, these recommendations are non-binding and the obligatory requirements do not exceed those of Cross Compliance. As a regulatory backbone to certification schemes, Cross Compliance has not managed to control ecological threats caused by agricultural intensification. The expert interviews revealed that negative developments, like a narrowing of crop rotation, cause continuously high digester output on arable land and an increased pressure on extensively used permanent and rotational grassland continue to be unaffected by Cross Compliance. Other criteria on structural biodiversity around fields, or the water management, are too unspecific and vague to contribute to positive ecological changes. In conclusion, it appears that Cross Compliance as a requirement for sustainable biofuel production in Germany is a fig leaf, because it results in the maintenance of the unsustainable status quo in Germany. In 2015, after this study was conducted, the EU's new Common Agricultural Policy introduced three Greening measures (Crop-Rotation, Ecological Focus Areas and conservation of Permanent Grassland) as additional mechanisms to support biodiversity and ecosystem services in European agricultural landscapes. First assessments on Ecological Focus Areas (EFAs) have shown that greening mainly finances the maintenance of existing farm structures and farmers predominantly implement productive EFA options, such as catch crops, nitrogen fixing crops and fallow land with little effect on agricultural biodiversity [65]. This confirms the conceptual assessment of greening finding that greening (as legally designed in 2013) will provide little support for agricultural biodiversity [66]. Instead of waiting for these long-winding, controversial and interest laden discussions on the European CAP to produce effective solutions, it seems more expedient to redirect and boost discussions on how certification schemes can ensure a truly sustainable production.

The assessment of certification schemes showed that the implementation of the requirements of BSO and EU RED triggered an establishment of completely new certification systems within a very short timeframe. In Germany, the two certification systems ISCC and REDcert were developed. Due to the political pressure for a fast installation of efficient and effective certification systems, both methods used the one-to-one approach, at least in Germany. REDcert implements a concept which does not correspond with the common definition of certification systems, as previously described. 
It neither applies a risk-based approach nor develops the standard in a multi-stakeholder consensus. Additionally, it adopted the sustainability criteria of the BSO in its entirety and correspondingly its low requirements in terms of abiotic criteria and agrobiodiversity. Even if the ISCC went beyond the requirements of $\mathrm{BSO}$ and implemented some comprehensible criteria, it is not certain whether these requirements would be implemented in Germany. This is again a result of the application of Cross Compliance and hence the missing discussion about sustainable feedstock cultivation in Germany. In terms of sustainability the RSB standard is the most complex and ambitious. It prescribes extensive requirements and even integrates progress requirements. Thus, it not only preserves the current agricultural cultivation, but also aims to improve it. However, most of the criteria specifications seem to be too abstract. During the interviews several experts asked for more specific definitions of the already highly multifaceted BSO-requirements. As the RSB provides less specific definitions, it is unclear whether all objectives are practicable or if further specification is needed prior to implementation.

It can be concluded that most of the assessed approaches lack sufficient coverage of issues linked to agricultural cultivation in Germany. Most of the experts interviewed note that during the phase of standard-setting of EU RED and BSO, the conditions and interests of developing and newly industrialized countries were particularly considered. This is to a great extent due to the negative developments linked to biofuel feedstock cultivation in these countries, such as the deforestation of savannahs and primary forests or the debates about "fuel tank or dinner plate". While it is important to explore risks of biofuel production in developing countries to production and consumption in Europe, it is also important not to marginalize the risks of biofuel production in Europe when designing innovative and effective policy tools.

Future biofuel policies will be judged by their ability to meet the expectations of sustainability in the biofuel sector, in particular concerning the effectiveness of existing and new certification schemes. Suggestions to meet these expectations would be to revise the framework of the EU RED. This includes a more transparent recognition process, the involvement of different stakeholders and the integration of a complaint mechanism. Furthermore, so far voluntary requirements could be specified as mandatory, e.g., with regard to social aspects, limited use of hazardous agrochemicals, impact assessment and monitoring, mitigation of adverse effects on the environment, strengthening of positive effects for affected communities and analysis of the impact on food production.

Author Contributions: Kirsten Selbmann designed the study and developed the idea of the article. Kirsten Selbmann and Lydia Pforte gathered and analyzed the data and wrote the paper.

Conflicts of Interest: The authors declare no conflict of interest.

\section{References}

1. Schubert, R.; Schellnhuber, H.J.; Buchmann, N.; Epiney, A.; Grießhammer, R.; Kulessa, M.E.; Messner, D.; Rahmstorf, S.; Schmid, J. Welt im Wandel: Zukunftsfähige Bioenergie und Nachhaltige Landnutzung; WBGU: Berlin, Germany, 2008. (In German)

2. BDBE (Bundesverband der Deutschen Bioethanolwirtschaft e.V.) (Ed.) Bundesverband der Deutschen Bioethanolwirtschaft e.V. Available online: http:/ / www.bdbe.de/ (accessed on 9 June 2016). (In German)

3. EC (European Commission) (Ed.) Grünbuch—Hin zu Einer Europäischen Strategie für Energieversorgungssicherheit; EC: Luxemburg, 2001. (In German)

4. Doornbosch, R.; Steenblik, R. Biofuels: Is the Cure Worse than the Disease? OECD-Study SG/SD/RT: Paris, France, 2007.

5. Anseeuw, W.; Wily, L.A.; Cotula, L.; Taylor, M. Land Rights and the Rush for Land; ILC: Rome, Italy, 2012.

6. Cotula, L.; Dyer, N.; Vermeulen, S. Fuelling Exclusion? The Biofuels Boom and Poor People's Access to Land; IIED: London, UK, 2008.

7. Garcez, C.A.G.G.; Vianna, J.N.D.S. Brazilian biodiesel policy: Social and environmental considerations of sustainability. Energy 2009, 34, 645-654. [CrossRef]

8. Obidzinski, K.; Andriani, R.; Komarudin, H.; Andrianto, A. Environmental and social impacts of oil palm plantations and their implications for biofuel production in Indonesia. Ecol. Soc. 2012, 17, 25-44. [CrossRef] 
9. Searchinger, T.; Heimlich, R. Avoiding Bioenergy Competition for Food Crops and Land; World Resources Institute: Washington, DC, USA, 2015.

10. Popp, J.; Lakner, Z.; Harangi-Rákos, M.; Fári, M. The effect of bioenergy expansion: Food, energy, and environment. Renew. Sustain. Energy Rev. 2014, 32, 559-578. [CrossRef]

11. Schleifer, P. Orchestrating sustainability: The case of European Union biofuel governance. Regul. Gov. $2013,7$. [CrossRef]

12. MIL (Ministerium für Infrastruktur und Landwirtschaft) (Ed.) Cross Compliance; MIL: Potsdam, Germany, 2010.

13. Baltic Biomass Network. Planning regional bioenergy resource use. In Interreg IIIB Project Handbook 2005-2007; Bericht Brandenburg: Eberswalde, Germany, 2007.

14. Dziewiaty, K.; Bernardy, P.; Maierhof, J.; Jansen, S.; Wellmann, L. Auswirkungen Zunehmender Biomassenutzung (EEG) auf die Artenvielfalt-Erarbeitung von Handlungsempfehlungen für den Schutz der Vögel der Agrarlandschaft; Bundesministeriums für Umwelt, Naturschutz und Reaktorsicherheit: Berlin, Germany, 2007. (In German)

15. Nitsch, J.; Krewitt, W.; Nast, M.; Viebahn, P.; Gärtner, S.O.; Pehnt, M.; Reinhardt, G.; Schmidt, R.; Uihlein, A.; Scheurlen, K.; et al. Ökologisch Optimierter Ausbau der Nutzung Erneuerbarer Energien in Deutschland; Forschungsvorhaben im Auftrag des Bundesministeriums für Umwelt, Naturschutz und Reaktorsicherheit: Berlin, Germany, 2004. (In German)

16. Schlegel, S.; Elbersen, B.; Kaphengst, T. Input to DG TREN Consultation on "Biofuel Issues in the New Legislation on the Promotion of Renewable Energy"; Ecologic-Institute for International and European Environmental Policy: Berlin, Germany, 2007.

17. Schoene, F; Wachholz, C. Klimaschutz in der Landwirtschaft; NABU: Berlin, Germany, 2010.

18. Fehrenbach, H.; Giegrich, J.; Reinhardt, G.; Schmitz, J.; Sayer, U.; Gretz, M.; Seizinger, E.; Lanje, K. Criteria for Sustainable Use of Bioenergy on a Global Scale; Texte 30/08; Umweltbundesamt: Dessau, Germany, 2008.

19. Van Dam, J.; Junginger, M.; Faaij, A.; Jürgens, I.; Best, G.; Fritsche, U. Overview of recent developments in sustainable biomass certification. Biomass Bioenergy 2008, 32, 749-780. [CrossRef]

20. DFT (Department for Transport) (Ed.) Carbon and Sustainability Reporting within the Renewable Transport Fuel Obligation-Requirements and Guidance; DFT: London, UK, 2008.

21. Fritsche, U.R.; Hünecke, K.; Hermann, A.; Schulze, F.; Wiegmann, K. Sustainability Standards for Bioenergy; Oekoinstitut, WWF: Frankfurt, Germany, 2006.

22. Henneberg, K.J.; Dragisic, C.; Haye, S.; Hewson, J.; Semroc, B.; Savy, C.; Wiegmann, K.; Fehrenbach, H.; Fritsche, U.R. The Power of Bioenergy-Related Standards to protect Biodiversity. Conserv. Biol. 2009, 24, 412-423. [CrossRef] [PubMed]

23. RSB (Roundtable of Sustainable Biofuel) (Ed.) RSB Standard for Risk Management; RSB-STD-60-001; RSB: Lausanne, Switzerland, 2010.

24. Ponte, S. Roundtabling sustainability: Lessons from the biofuel industry. Geoforum 2013, 54, $261-271$. [CrossRef]

25. Lewandowski, I.; Faaij, A. Steps towards the development of a certification system for sustainable bio-energy trade. Biomass Bioenergy 2004, 30, 83-104. [CrossRef]

26. Forest Stewardship Council. About US. Available online: https://ic.fsc.org/ (accessed on 3 August 2016).

27. Hamelinck, C.; van den Heuvel, E.; Bergsma, E.; Junginger, M.; Smeets, E.; Faaij, A. Criteria for Sustainable Biomass Production; Final Report of the Project Group "Sustainable Production of Biomass"; Utrecht University: Utrecht, The Netherlands, 2006.

28. Hasenberg, V. (Ed.) Biokraftstoffe-Potenziale, Herausforderungen und Wege Einer Nachhaltigen Nutzung; Diplomica Verlage GmbH: Hamburg, Germany, 2009.

29. Dehue, B.; Meyer, S.; Hamelink, C. Towards a Harmonized Sustainable Biomass Certification Scheme; Ecofys: Utrechte, The Netherlands, 2007.

30. Schlegel, S.; Kaphengst, T. European Union Policy on Bioenergy and the Role of Sustainability Criteria in Certification Systems. J. Agric. Food Ind. Organ. 2007, 5. [CrossRef]

31. Glaeser, J.; Laudel, G. Experteninterviews und Qualitative Inhaltsanalyse; VS Verlag: Wiesbaden, Germany, 2009.

32. Bogner, A.; Menz, W. Expertenwissen und Forschungspraxis: Die modernisierungstheoretische und die methodische Debatte um die Experten. In Das Experteninterview: Theorie, Methode, Anwendung; Bogner, A., Menz, W., Eds.; VS Verlag: Wiesbaden, Germany, 2005; pp. 7-31. 
33. Meuser, M.; Nagel, U. ExpertInneninterview: Zur Rekonstruktion Spezialisierten Sonderwissens. In Handbuch Frauen- und Geschlechterforschung; Springer: Berlin, Germany, 2008. (In German)

34. LUA (Landesumweltamt Brandenburg). Umweltdaten Brandenburg; LUA: Potsdam, Germany, 2009.

35. BFN (Bundesamt für Naturschutz) (Ed.) Steckbriefe der Natura 2000 Gebiete; BFN: Bonn, Germany, 2010.

36. NABU (Naturschutzbund Deutschland e.V.) (Ed.) Mit der Landwirtschaft zu mehr Natur. Berlin. Available online: http://www.nabu.de/themen/landwirtschaft/landwirtschaftundnaturschutz/index.html (accessed on 9 June 2016).

37. LUA (Landesumweltamt Brandenburg) (Ed.) Umsetzung der Wasserrahmenrichtlinie. C-Bericht; Landesumweltamt Brandenburg: Potsdam, Germany, 2005. (In German)

38. Gerstengarbe, F.W.; Badeck, F.; Hattermann, F.; Krysanova, V.; Lahmer, W.; Lasch, P.; Stock, M.; Suckow, F.; Wechsung, F.; Werner, P.C. Studie zur Klimatischen Entwicklung im Land Brandenburg bis 2055 und Deren Auswirkungen auf den Wasserhaushalt, Die Forst- und Landwirtschaft Sowie Die Ableitung Erster Perspektiven; Potsdam-Institut für Klimafolgenforschung: Potsdam, Germany, 2003. (In German)

39. FAO (Food and Agriculture Organization) (Ed.) What Is Agrobiodiversity? Fact Sheet of Training Manual "Building on Gender, Agrobiodiversity and Local knowledge"; FAO: Rome, Italy, 2000.

40. LUGV (Landesamt für Umwelt, Gesundheit und Verbraucherschutz Brandenburg) (Ed.) Rote Liste Brutvögel. 2009. Available online: http://www.mugv.brandenburg.de/cms/detail.php/bb2.c.545328.de (accessed on 9 June 2016).

41. Hannemann, J. Erosionsgefährdung durch Wasser und Wind im Land Brandenburg. Available online: http:/ / necs.org/conference/venues/ (accessed on 9 June 2016).

42. LUA (Landesumweltamt Brandenburg) (Ed.) Schutzgebiete. Natur- und Landschaftsschutz/Natura 2000; LUA: Potsdam, Germany, 2010.

43. Roschke, M.; von Gagern, W. Ergebnisse aus Dauerfeldversuchen zur Erhaltung der Bodenfruchtbarkeit. Arch. Agron. Soil Sci. 2004, 51, 119-124. [CrossRef]

44. Pellnitz, K. Nutzungskonflikte bei Nachwachsenden Rohstoffen-Ursachen und Lösungen; Wissenschaftsverbund Umwelt: Rostock, Germany, 2008. (In German)

45. Arndt, M. Einfluss von Fruchtfolge, chemischen und biologischen Bekämpfungsmaßnahmen auf die Befallsentwicklung von Rübennematoden (Heterodera schachtii) und den Zuckerrübenertrag. Gesunde Pflanz. 2002, 54, 3-4. [CrossRef]

46. Kiefer, J.; Ball, T. Beurteilung der Erzeugung von Biomasse zur energetische Nutzung aus Sicht des Gewässerschutzes. Wasserpraxis 2008, 6, 36-43.

47. Peters, W. Auswirkungen des Energiepflanzenanbaus auf Natur und Landschaft; Protokoll Bundesumwelt ministerium: Berlin, Germany, 2007. (In German)

48. Bundesregierung Deutschland (BReg) (Ed.) Verordnung über Anforderungen an Eine Nachhaltige Herstellung von Biokraftstoffen (Biokraft-NachV); BGB IS. 3182; Bundesregierung Deutschland: Bonn, Germany, 2009. (In German)

49. ISCC (International Sustainability and Carbon Certification) (Ed.) NachhaltigkeitsanforderungenAnforderungen an die Herstellung von Biomasse (Pflanzenanbau); ISCC 202; ISCC: Koeln, Germany, 2010. (In German)

50. EC (European Commission) (Ed.) Verordnung (EG) Nr. 73/2009 des Rates mit Gemeinsamen Regeln für Direktzahlungen im Rahmen der Gemeinsamen Agrarpolitik und mit Bestimmten Stützungsregelungen für Inhaber landwirtschaftlicher Betriebe und zur Änderung der Verordnungen (EG) Nr. 1290/2005, (EG) Nr. 247/2006, (EG) Nr. 378/2007 sowie zur Aufhebung der Verordnung (EG) Nr. 1782/2003; EC: Brussels, Belgium, 2009. (In German)

51. REDcert (Ed.) Systemgrundsätze für die Prozessstufe Ersterfasser zur Umsetzung der Biomasse-Nachhaltigkeit sverordnungen; Version 15-06-2010; REDcert: Berlin, Germany, 2010. (In German)

52. RSB (Roundtable of Sustainable Biofuel) (Ed.) RSB Guidance on Principle \& Criteria for Sustainable Biofuel Production; RSB-GUI-01-001; RSB: Lausanne, Switzerland, 2010.

53. BLE (Bundesanstalt für Ernährung) (Ed.) Antrag Zertifizierungssystem (Biokraftstoff-NachV). 2010. Available online: http:/ / www.ble.de/ (accessed on 9 June 2016).

54. LUGV (Landesamt für Umwelt, Gesundheit und Verbraucherschutz Brandenburg) (Ed.) Schutzgebietszonen, 2009. Available online: http://www.mugv.brandenburg.de/cms/detail.php/lbm1.c.367587.de (accessed on 9 June 2016). 
55. MIL (Ministerium für Infrastruktur und Landwirtschaft) (Ed.) Übersicht Förderung Programm KULAP 2000. Potsdam. Available online: http://www.mil.brandenburg.de/cms/detail.php/bb1.c.213921.de (accessed on 9 June 2016).

56. MIL (Ministerium für Infrastruktur und Landwirtschaft) (Ed.) Übersicht Förderung Programm KULAP 2007. Potsdam. Available online: http:/ / www.mil.brandenburg.de/cms/detail.php/bb1.c.213972.de (accessed on 9 June 2016).

57. MUGV (Ministerium für Umwelt, Gesundheit und Verbraucherschutz) (Ed.) Landschaftsschutzgebiete in Brandenburg, 2010. Potsdam. Available online: http://www.mugv.brandenburg.de/cms/media.php/lbm1. a.2338.de/lsg_liste.pdf (accessed on 9 June 2016).

58. BLE (Bundesanstalt für Ernährung) (Ed.) Leitfaden Nachhaltige Biomasseherstellung; BLE: Bonn, Germany, 2010.

59. MUGV (Ministerium für Umwelt, Gesundheit und Verbraucherschutz) (Ed.) Agrarbericht 2009 zur Land- und Ernährungswirtschaft des Landes Brandenburg; MUGV: Potsdam, Germany, 2009.

60. Agentur für Erneuerbare Energien (Ed.) Biokraftstoffe-Daten und Fakten 2009; Agentur für Erneuerbare Energien: Berlin, Germany, 2009.

61. RFA (Renewable Fuels Agency) (Ed.) Carbon and Sustainability Reporting within the Renewable Transport Fuel Obligation-Technical Guidance Part One, Version 2.0; RFA: East Sussex, UK, 2009.

62. RFA (Renewable Fuels Agency) (Ed.) Carbon and Sustainability Reporting within the Renewable Transport Fuel Obligation-Technical Guidance Part One, Version 4.2; RFA: East Sussex, UK, 2011.

63. BMELV (Bundesministeriums für Ernährung, Landwirtschaft und Verbraucherschutz) (Ed.) Die EUAgrarreform-Umsetzung in Deutschland; BMELV: Berlin, Germany, 2006.

64. Breitschuh, G.; Reinhold, G.; Breitschuh, T. Ökologische Konsequenzen (einschließlich CC) des Anbaus und der Verwendung Nachwachsender Biograsrohstoffe; Thüringer Landesanstalt für Landwirtschaft: Jena, Germany, 2006.

65. Lakner, S.; Schmitt, J.; Schueler, S.; Zinngrebe, Y. Naturschutzpolitik in der Landwirtschaft: Erfahrungen aus der Umsetzung von Greening und der ökologischen Vorrangfläche 2015. In Konferenzbeitrag für die 56, Proceedings of the Gewisola Tagung "Agrar- und Ernährungswirtschaft: Regional Vernetzt und Global Erfolgreich”, Bonn, Germany, 28-30 September 2016; Rheinische Friedrich-Wilhelms Universität: Bonn, Germany, 2016.

66. Pe'er, G.; Dicks, L.; Visconti, P.; Arlettaz, R.; Báldi, A.; Bengton, T.; Collins, S.; Dietrich, M.; Gregory, R.; Hartig, F.; et al. EU agricultural reform fails on biodiversity. Science 2014, 344, 1090-1092. [CrossRef] [PubMed]

(C) 2016 by the authors; licensee MDPI, Basel, Switzerland. This article is an open access article distributed under the terms and conditions of the Creative Commons Attribution (CC-BY) license (http://creativecommons.org/licenses/by/4.0/). 